\section{"Never mind, when is dinner ready?" Living with Prader-Willi syndrome}

$\mathrm{T}$ he cat died when Rachel was 151/4. Ginger was loved and cuddled by Rachel every day for every one of his 12 years. Ginger's life was defined by the search for warmth on Rachel's bed and a regular supply of food. Rachel's chromosomes determine that her life is lived through the experience of PraderWilli syndrome.

It is unfortunate that in Rachel's short life I have now on six occasions told her that a creature (three human, three animal) whom she has loved, albeit in varying degrees, has died. It's hard to imagine how I would feel if that were me. I can guess though: I have ranted, cried, sniffled, shrugged. I have experienced overwhelming grief, sadness, anger, and sometimes, a sense of relief.

Rachel's response to Ginger's death was: "Oh well Mum, come on now." Then she asked would I be getting her tea soon.

I return to the endless refrain that tumbles through my head: I do not know what it feels like to be Rachel. Absolute presumption-how dare I? I do not know what it feels like to be you.

I realise that my experiences and yours are unique. And yet as I explained the cat's death to my then 19 year old son, I could safely anticipate his sadness. We could talk about our shared sorrow and, with some guilt, the ability now to sling a black jumper on the sofa and know it wouldn't be carpeted by Ginger's shed hair.

Of course, it would be wrong for me to expect Rachel to react to Ginger's sad demise on my terms. Could it be simply language? Although Rachel can talk for all her waking hours, perhaps her language does not have the richness and elasticity we need in order to express the intensity of grief.

Rachel, I know, experienced feelings of loss, sorrow and regret. I cannot judge the full range or gauge the depth. I know because I experience her as a child charging emotionally-with the full range of pleasure, anger, delight, joy, sadness-through every day. The volatility of living with Rachel's emotions sets an edge on the hours of her wakefulness. It is like sitting in the dentist's chair: all is well for now, but in a second the drill will bite home.

This, however, was a real situation for an emotional expression. I hadn't just said "no" to coming to the supermarket with me (a withdrawn sulk, followed by sobs at being abandoned). Neither had I
Here, a mother of a young person with Prader-Willi syndrome reminds us that their inexorable and overwhelming hypothalamic drive makes them incapable of responding rationally to discussions about food.

The Prader-Willi Syndrome Association (UK) can be contacted at www. pwsa.co.uk.

just misplaced that puzzle piece (hysteria that it was utterly lost and the puzzle, indeed life, never able to be completed).

Three years on from this incident, Rachel is a "young adult", but I still do not know how it feels to be Rachel. She watched my tears then, watched me empty the cupboard of cat food. Today, she hears the delight in my voice when her brother phones, hears my utter despair when trying to reason with her through her tantrum. She makes no more comment today, than then.

Instead, she chatters on about the Christmas dinner at school. If she senses some absence of attention she may ask if I'm all right. She often continues her chatter before I answer. But then, in relation to nothing at all, she may suddenly appear and lovingly squeeze my arm: "I love you, mummy. How would I live without you?".

I return the sentiment and hug. She then beams up at me: "Can I have pasta and lamb casserole for dinner mum?".

The anecdote of the dead pet is not to portray an unfeeling child; she is always moved to tears in weepy films. She genuinely cares about me and our dog. But if I point out the sadness of dying refugees, she demurs, without conviction, and continues with her current conversation.

Neither can I accuse her of selfishness. She spent all of last Saturday wrapping Christmas presents that she had made and bought for her brother and myself. But later, tomorrow perhaps, I may ask her to eat breakfast, or shower in a different order, or at a different time, so that I can accomplish some small task. She may very well smile and say "Of course, mum, anything to help."

Or she may instead, simply refuse, deaf to explanations. Sensing a potential loss of control, or routine, she may

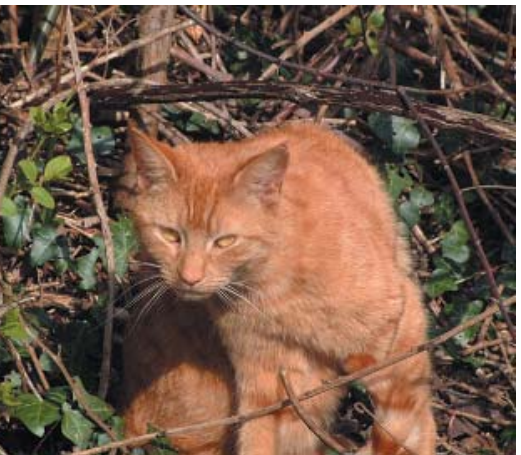

quickly whirlwind into a fury of obdurate refusal to cooperate with anything. In such moments, I know that if I told her that my life depended on her cooperation, I would be about to inhale my last breath.

Finally, of course, the food. I have no pleasure in food when Rachel is around. But with my metabolic rate and build, my $7 \frac{1}{2}$ stone can delight-and does in any delectable morsel. Rachel weighs 13 stone. She is always hungry. She can never eat between meals. She nearly always spills food on her clothes at meal times. Disgusting and infuriating, in a bright young woman? Certainly. But I discovered recently, that it is her coping strategy: she told a family friend on an outing, that if she cannot remember eating her lunch, she only has to look and see if there are spills, and thereby find reassuring proof of eating.

I cannot imagine what it feels like to be Rachel.

Finally, how can the health professionals and doctors who have become involved with us, help? Above all, I would ask that they accept that they cannot rationalise with the apparently rational child before them, if it in any way threatens the ordered meals of the day. They cannot explain processes to the apparently intelligent child before them, if she is already convinced by her own perceptions. And the parent on edge, with this apparently affable child, has learned that at any moment, the calm of that consultation may be ravaged by unstoppable fury, implacable rage.

Jennie Bamford

Correspondence to: $\mathrm{Dr} \mathrm{H}$ Marcovitch, Syndication Editor, BMJ Publications; h.marcovitch@btinternet.com 